\title{
Research Article \\ Effect of Priming and Seed Size on Germination and Emergence of Six Food-Type Soybean Varieties
}

\author{
Maru K. Kering ${ }^{1}$ and Bo Zhang ${ }^{2}$ \\ ${ }^{1}$ Agricultural Research Station, Virginia State University, P.O. Box 9061, Petersburg, VA 23806, USA \\ ${ }^{2}$ Virginia Polytechnic Institute and State University, Blacksburg, VA 24061, USA \\ Correspondence should be addressed to Maru K. Kering; mkering@vsu.edu
}

Received 30 September 2015; Revised 22 November 2015; Accepted 23 November 2015

Academic Editor: Iskender Tiryaki

Copyright (c) 2015 M. K. Kering and B. Zhang. This is an open access article distributed under the Creative Commons Attribution License, which permits unrestricted use, distribution, and reproduction in any medium, provided the original work is properly cited.

Soybean (Glycine $\max$ (L.) Merr.), a good source of protein and oil, is used to produce nutritious isoflavone-rich soybean-based foods. The objectives of this study were (i) to determine the germination difference among soybean seeds in various seed sizes and (ii) to evaluate effects of seed pretreatment on germination and seedling emergence. Six varieties of different seed size class were used: (i) small size (MFS-561 and V08-4773), (ii) medium size (Glen and V03-47050), and (iii) large size (MFL-159 and V07-1897). Pregermination treatments include 0,5 , or 10 hours soaking and germinating/planting with or without nitrogen fertilizer. Large seed size varieties showed low germination rate and $\mathrm{N}$ addition caused the least reduction in germination in these seeds during the first 24 hours. While $\mathrm{N}$ had no effect on seed germination after 72 hours, growth in $\mathrm{N}$ treated seed was low. Seedling emergence was comparable across varieties in 2013 and water priming and $\mathrm{N}$ application had no effect. However, while varieties did not differ in final emergence for nonprimed seeds in 2014, water priming led to a high reduction in seedling emergence of large seed varieties in this study. Application of $\mathrm{N}$ fertilizer had no effect on seedling emergence in field experiments.

\section{Introduction}

Soybean is one of the most important sources of protein and oil and has industrial application due to its nutriceutical and pharmaceutical benefits. The global demand of foodgrade soybeans is on the increase in both traditional Asian markets and new world markets. In the US, demand of foodtype soybeans for direct consumption like the vegetabletype (edamame) has been increasing due to the proven and publicized nutritional values and health benefits $[1,2]$. It is the recognition of these nutritional quality attributes that led USDA to recommend the provision of soy-based products in school feeding programs [3]. In 2013, 31\% of Americans consumed soyfoods or soy beverages at least once a week or more, compared to $24 \%$ in 2010 , and the current US retail market for soyfoods was approximately $\$ 4.5$ billion in 2013 compared to 1 billion in 1996 [4]. The expanding soybeanbased food market in Japan and the US has generated considerable interest among American soybean producers in recent years.
The most popular soyfoods, like soymilk, tofu, and vegetable soybean (edamame), are all produced mainly from large-seeded (>20 g/100 seeds) soybeans [5]. Large-seeded soybeans are reported to increase quantity and strength of tofu and had higher total content of monounsaturated oils $[6,7]$. Soymilk sales have reached 210.5 million in 2013 while tofu as a traditional soyfood had sales of approximately $\$ 274$ million in 2013 [4]. Differences in seedling emergence and vigor and the subsequent crop stand are reportedly attributed to prevailing seedbed conditions [8]. The effects of seed size on germination and subsequent yield also vary with some showing increased yield with seed size [9] and others showing no effect [10]. It has been reported that seed size correlates with seed vigor and that large seeds tend to produce more vigorous seedlings and better stand [11, 12] and more likely to emerge from greater depth than those from small seeds [13]. Plants from larger seeds have been reported to produce bigger seed yield than those from small kernels [14, 15]. However, other results indicate better germination and vigor in small and medium sized seeds [16] and other showed no 
TABLE 1: Table showing the $P$ values for main variable and their interactions in laboratory experiments.

\begin{tabular}{lccc}
\hline & & Time since start of experiment (hours) \\
Variety & 24 & 48 & $P$ value \\
& & $<0.0001$ & $<0.0001$ \\
Variety & $<0.0001$ & 0.4719 & 0.0144 \\
Water priming & $<0.0001$ & 0.0002 & 0.0204 \\
Nitrogen & $<0.0001$ & 0.9352 & 0.4557 \\
Variety $*$ water priming & 0.0051 & 0.9952 & 0.8253 \\
Variety $*$ nitrogen & 0.0014 & 0.4332 & 0.6015 \\
Water priming $*$ nitrogen & 0.0003 & 0.9744 & 0.9981 \\
Variety $*$ water priming $*$ nitrogen & 0.0666 & & \\
\hline
\end{tabular}

relationship between seed size and seedling emergence and final yield [17]. Also addition of fertilizer to hydroprimed seeds could affect plant growth and yield as shown for sulfur which resulted in an increase in yield in both primed and nonprimed seeds [18]. Soil factors play a role in germination and subsequent yield of a crop. Under ideal soil moisture conditions, large soybean seeds showed better physiological quality than small seeds; with more vigorous seedling but at moisture content of $-0.2 \mathrm{MPa}$, small seed performed better [19]. Other edaphic factors like salinity affect germination by creating osmotic potentials, preventing seed water uptake, as well as direct toxic effects of $\mathrm{Na}^{+}$and $\mathrm{Cl}^{-}$[20]. At moisture content ranging from 20 to $30 \%$, all soybean seed sizes showed no germination at $20 \%$ moisture content, but small and medium sized seeds showed better germination and greater root developments than large sized seeds at all higher moisture content [21].

During seasons with below average growing conditions, rate of large-seeded soybean may need to be adjusted to compensate for anticipated low germination. However, because future weather conditions are not easy to predict, management strategies to improve germination and emergence of large-seeded soybean are required to equip food-grade soybean farmers with high production efficiency. Increased production efficiency will likely lead to increased yield and improved economic returns to soybean producers. This study was carried out with the following objectives: (i) to discover the germination difference of soybean seeds in various sizes and (ii) to determine the effect of seed priming on germination rate and emergence of food-type soybeans.

\section{Materials and Methods}

2.1. Laboratory Experiments. The experiment was carried out at the research laboratories at MT Carter Building, Virginia State University. The soybean varieties used were harvested at Virginia Polytechnic Institute and State University (Blacksburg, VA). The varieties of soybean used were two small-seeded varieties $(<10 \mathrm{~g} / 100$ seeds; MFS-561 and V08-4773): two medium sized seed varieties (between 12 and $16 \mathrm{~g} / 100$ seeds; Glenn and V03-4705): two largeseeded varieties (>20 g/100 seeds; MFL-159 and V07-1897). The same seed lot was used for the two years of study. The pregermination treatments were 5 or 10 hours of soaking in water. At the start of germination or field planting, seeds with/without hydropriming were put in petri dish with water-only (laboratory-only) or a solution of nitrogen fertilizer (laboratory and field). In laboratory experiments, constant monitoring ensured sufficient moisture throughout the experiment period. Each treatment unit consists of 50 seeds and was replicated three times. Germination was done at laboratory temperatures. The number of seeds germinated as indicated by the radicle emergence was determined everyday starting from the day after start of germination until all seeds germinate or germinated number remains constant. In the laboratory experiment, germination was defined as emergence of and a visible radicle of $1 \mathrm{~mm}$ length.

2.2. Field Experiment. In the field, experiment was laid out as a complete block design at Randolph Farm, Virginia State University. The same treatments as in the laboratory experiment were used with three replications. The same seed lots were used for both 2013 and 2014 studies. In each $1.5 \mathrm{~m}$ experimental unit, 50 seeds were planted and number of emerged seedlings were determined preferably on a daily basis beginning 8 days after planting. The same seed lots were used in 2013 and 2014 planting. The number of emerged seedlings in each treatment replication was recorded daily until no additional seedlings emerged. Because of differences in rainfall and soil moisture condition at time of planting between the two years, seedling emergence is reported independently for each year of production. Statistical analyses were done using PROC MIX Procedures in SAS.

\subsection{Laboratory Results}

2.3.1. Seed Germination. During the first 24 hours all twoway interaction between variety, hydropriming duration, and nitrogen affected seed germination (Table 1). Subsequently, at 48 and 72 hours, only main factors affected seed germination except for water priming at 48 hours (Table 1). The number of seeds germinated after 24 hours increased with increase in duration of hydropriming in all varieties (Table 2(a)). For all hydropriming duration, small- and medium-seeded varieties showed the highest number of germinated seeds compared to large-seeded varieties. In fact for a 10-hour priming duration, germination in small-seeded varieties was 2-3 times higher than that of large-seeded varieties. 
TABLE 2: (a) Percentage of germination of soybean variety affected by water priming duration and variety under laboratory temperatures 24 hours after start of experiment. (b) Percentage of germination of soybean variety affected by variety and nitrogen fertilizer application laboratory temperatures 24 hours after start of experiment. (c) Percentage of germination of soybean variety affected by variety and nitrogen fertilizer application laboratory temperatures 48 and 72 hours after start of experiment.

(a)

\begin{tabular}{lcccc}
\hline \multirow{2}{*}{ Seed size class } & \multicolumn{4}{c}{ Hydropriming duration (hours) } \\
& & 0 (none) & 5 & 10 \\
& & & $\%$ & \\
\hline Small & MFS-561 & $3.6 \mathrm{fghi}$ & $24.2 \mathrm{c}$ & $83.7 \mathrm{a}$ \\
Small & V08-4773 & $4.9 \mathrm{efg}$ & $7.8 \mathrm{de}$ & $61.8 \mathrm{a}$ \\
Medium & V03-4705 & $2.2 \mathrm{ij}$ & $4.4 \mathrm{fgh}$ & $34.8 \mathrm{bc}$ \\
Medium & Glenn & $4.0 \mathrm{fgh}$ & $9.6 \mathrm{~d}$ & $52.0 \mathrm{ab}$ \\
Large & V07-1897 & $2.0 \mathrm{j}$ & $5.4 \mathrm{ef}$ & $26.5 \mathrm{c}$ \\
Large & MFL-159 & $2.8 \mathrm{hij}$ & $3.0 \mathrm{ghij}$ & $30.4 \mathrm{c}$ \\
\hline
\end{tabular}

Numbers followed by a similar letter are not statistically different $(P=0.05)$.

(b)

\begin{tabular}{lccc}
\hline & & \multicolumn{2}{c}{ Nitrogen status } \\
& & $-\mathrm{N}$ & $+\mathrm{N}$ \\
\hline Small & MFS-561 & $31.4 \mathrm{a}$ & $12.1 \mathrm{~b}$ \\
Small & V08-4773 & $24.7 \mathrm{a}$ & $7.2 \mathrm{~cd}$ \\
Medium & V03-4705 & $8.9 \mathrm{bc}$ & $5.5 \mathrm{~d}$ \\
Medium & Glenn & $20.9 \mathrm{a}$ & $7.6 \mathrm{~cd}$ \\
Large & V07-1897 & $6.8 \mathrm{~cd}$ & $6.3 \mathrm{~cd}$ \\
Large & MFL-159 & $7.4 \mathrm{~cd}$ & $5.5 \mathrm{~d}$ \\
\hline
\end{tabular}

Numbers followed by a similar letter are not statistically different $(P=0.05)$.

(c)

\begin{tabular}{lccc}
\hline \multirow{2}{*}{ Seed size class } & \multirow{2}{*}{ Variety } & \multicolumn{2}{c}{ Hours after start of experiment } \\
& & 48 & 72 \\
\hline Small & MFS-561 & $88.0 \mathrm{a}$ & $99.7 \mathrm{a}$ \\
Small & V08-4773 & $79.1 \mathrm{a}$ & $93.1 \mathrm{a}$ \\
Medium & V03-4705 & $75.7 \mathrm{a}$ & $92.1 \mathrm{a}$ \\
Medium & Glenn & $70.5 \mathrm{a}$ & $91.3 \mathrm{a}$ \\
Large & V07-1897 & $29.4 \mathrm{~b}$ & $45.5 \mathrm{~b}$ \\
Large & MFL-159 & $28.9 \mathrm{~b}$ & $44.9 \mathrm{~b}$
\end{tabular}

Numbers in a column followed by a similar letter are not statistically different $(P=0.05)$.

After 48 and 72 hours, small- and medium-seeded varieties showed similar germination that was bigger $(P<0.05)$ than that for large-seeded varieties. In small- and mediumseeded varieties, germination reached over $70 \%$ and $90 \%$ after 48 and 72 hours, respectively (Table 2(c)). At 48 and 72 hours, germination in large-seeded varieties was below 30 and 50\%, respectively. This agrees with other findings that showed up to $59 \%$ reduction in germination time with hydropriming in seeds of several grain crops [22]. Similar results were reported for cotton and maize in semiarid environments [23]. During the first 24 hours, variety and nitrogen fertilizer application significantly $(P<0.0001)$ affected seed germination with those receiving $\mathrm{N}$ fertilizer showing lower germination (Table 2(b)). Across varieties, increased priming time increased number of germinated seeds at 24 hours with or without $\mathrm{N}$ fertilizer addition (data not shown). Across varieties, germination for $\mathrm{N}$-treated and non- $\mathrm{N}$ treated seeds was $48 \%$ and $65 \%$ and $68 \%$ and $79 \%$, at 48 and 72 hours, respectively (data not shown). The reduction in germination with $\mathrm{N}$ application was observed in small and medium sized varieties and not in large-seeded varieties. In fact, the reduction for small-seeded varieties averaged $65 \%$ while in large-seeded varieties it averaged $13 \%$. This effect of $\mathrm{N}$ on germination is supported by the relative greenness between $\mathrm{N}$-treated and no-N-treated germinating seeds at 72 hours (Figure 1). With high surface area to volume ratio, small seeds may have imbibed a lot of $\mathrm{N}$ causing higher physiological drought than that in large seeds. This may have reduced remobilization of nutrient for use in germination. Similar reduction in germination with fertilizer application has been reported by others [24].

\section{Result of Field Grown Plants}

3.1. Seedling Emergence. In 2013, except for variety, none of the factors nor their interactions and the three-way interactions significantly $(P=0.05)$ affected seedling emergence for all days where emergence data was determined (Table 4). However, in 2014, variety and water priming and its interaction significantly $(P=0.05)$ affected seedling emergence (Table 4). While some studies have shown that priming with fertilizer reduces germination and emergence [24], this study showed that $\mathrm{N}$ fertilizer application had no effect on seedling emergence. Similarly, lack of improved field emergence of soybean with sulphur application was reported [19]. In winter wheat hydropriming or priming with a number of salt solution failed to improve seedling emergence in winter wheat [25]. The number of seedlings during the first day of emergence did not differ with varieties in 2013 and averaged about $13.3 \%$ (Table 5). Small-seeded varieties showed an average emergence of $11.3 \%$ which was higher than that of large sized seed varieties V07-1897 and MFL159 that was below 6\% (Table 5). In the subsequent days in 2013, large-seeded V07-1897 maintained a higher emergence compared to all small-seeded varieties and was comparable in most cases to the medium sized seeded varieties (Table 5). At the end of seedling emergence, V07-1897 showed $83.6 \%$ emergence that is similar $(P=0.05)$ to $74.6 \%$ observed in medium sized seed variety V03-4705 but higher than all others averaged at $68.2 \%$. In general in 2014, seeds receiving no water priming showed better emergence than primed seeds (Table 6 ). While water priming for 5 or 10 hours showed improved emergence in small- and medium-seeded varieties earlier, it reduced emergence in large-seeded varieties (Table 6) However, while seedling emergence in 50\% of small and medium sized varieties was comparable among water priming treatment at $\geq 16$ days after planting, nonprimed seeds maintained higher emergence in large-seeded varieties up till end of the observation period. Across water-primed 


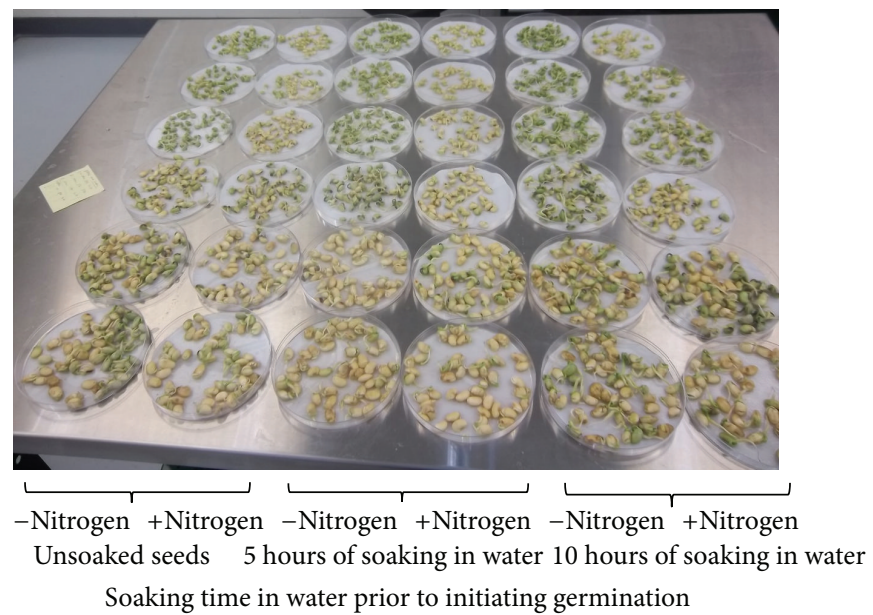

FIGURE 1: From fore- to background row there are two rows, each of large, medium, and small sized seed varieties, 72 hours after start of germination study.

TABLE 3: Biweekly precipitation during the months of May through September of 2013 and 2014 near Petersburg, VA.

\begin{tabular}{|c|c|c|c|c|c|c|c|c|c|c|}
\hline \multirow[b]{2}{*}{ Day of the month } & \multicolumn{2}{|c|}{ May } & \multicolumn{2}{|c|}{ June } & \multicolumn{2}{|c|}{ July } & \multicolumn{2}{|c|}{ August } & \multicolumn{2}{|c|}{ September } \\
\hline & 2013 & 2014 & 2013 & 2014 & 2013 & 2014 & 2013 & 2014 & 2013 & 2014 \\
\hline & \multicolumn{10}{|c|}{$\mathrm{mm}$} \\
\hline First 15 days & 18.3 & 11.7 & 154.9 & 59.2 & 63.7 & 14.0 & 108.7 & 61.0 & 10.2 & 36.3 \\
\hline Last 15 (16) days & 70.4 & 6.3 & 81.8 & 37.1 & 53.1 & 105.9 & 46.5 & 88.6 & 0.3 & 26.7 \\
\hline Total monthly precipitation & 88.7 & 18.0 & 236.7 & 96.3 & 116.8 & 145.9 & 155.2 & 149.6 & 10.5 & 63.0 \\
\hline
\end{tabular}

TABLE 4: Table showing the $P$ values for independent variable and their interactions.

\begin{tabular}{|c|c|c|c|c|c|c|}
\hline & \multicolumn{6}{|c|}{ Days after planting } \\
\hline & 8 & 9 & 10 & 15 & 16 & 20 \\
\hline & \multicolumn{6}{|c|}{2013} \\
\hline Variety & 0.7869 & 0.0487 & 0.0514 & 0.0499 & 0.0501 & - \\
\hline Water priming & 0.2726 & 0.7677 & 0.7281 & 0.5859 & 0.5589 & - \\
\hline Nitrogen & 0.3882 & 0.1705 & 0.0925 & 0.0932 & 0.0934 & - \\
\hline Variety $*$ water priming & 0.5814 & 0.8682 & 0.9483 & 0.9394 & 0.9398 & - \\
\hline Variety $*$ nitrogen & 0.6577 & 0.9791 & 0.9339 & 0.9644 & 0.9640 & - \\
\hline Water $*$ nitrogen & 0.6551 & 0.5749 & 0.6350 & 0.4786 & 0.4464 & - \\
\hline \multirow[t]{2}{*}{ Variety $*$ water priming $*$ nitrogen } & 0.4873 & 0.5894 & 0.3675 & 0.2003 & 0.1938 & - \\
\hline & \multicolumn{6}{|c|}{2014} \\
\hline Variety & $<0.0001$ & $<0.0001$ & $<0.0001$ & $<0.0001$ & $<0.0001$ & $<0.0001$ \\
\hline Water priming & $<0.0001$ & $<0.0001$ & $<0.0001$ & $<0.0001$ & $<0.0001$ & $<0.0001$ \\
\hline Nitrogen & 0.2295 & 0.1961 & 0.5610 & 0.2309 & 0.2580 & 0.1999 \\
\hline Variety $*$ water priming & $<0.0001$ & $<0.0001$ & $<0.0001$ & $<0.0001$ & $<0.0001$ & $<0.0001$ \\
\hline Variety $*$ nitrogen & 0.7632 & 0.5227 & 0.4794 & 0.2753 & 0.6523 & 0.7774 \\
\hline Water $*$ nitrogen & 0.1098 & 0.5365 & 0.1531 & 0.1105 & 0.0541 & 0.1210 \\
\hline Variety $*$ water priming $*$ nitrogen & 0.4988 & 0.9679 & 0.9338 & 0.9411 & 0.9120 & 0.9162 \\
\hline
\end{tabular}

treatments, medium sized seeded variety Glenn maintained a higher $(P=0.05)$ emergence percent than others and reached $70 \%$ at the end of the observation period. Largeseeded varieties maintained the lowest emergence percent and reached only $18.7 \%$ by end of the observation. These results are in agreement with those reported earlier where small and medium sized seeds gave a more rapid emergence than large sized seeds [21]. In general, the relatively high emergence of seedlings in 2013 compared to 2014 may be due to prevailing soil moisture condition. During the last two weeks of May and the first two weeks of June, a period encompassing the planting time, total precipitation was $225.3 \mathrm{~mm}$ in 2013 and only $65.3 \mathrm{~mm}$ in 2014 (Table 3). Similarly, the almost comparable emergence between small- 
TABLE 5: Seedling emergence as a percentage of seeds planted in the field in 2013.

\begin{tabular}{|c|c|c|c|c|c|c|}
\hline \multirow[b]{2}{*}{ Seed size class } & \multirow[b]{2}{*}{ Variety } & \multicolumn{5}{|c|}{ Day after planting } \\
\hline & & 8 & 9 & 10 & 15 & 16 \\
\hline & & \multicolumn{5}{|c|}{$\%$} \\
\hline Small & MFS-561 & $12.7 \mathrm{a}$ & $35.7 b$ & $52.1 \mathrm{~b}$ & $67.8 \mathrm{~b}$ & $67.8 \mathrm{~b}$ \\
\hline Small & V08-4773 & $9.0 \mathrm{a}$ & $35.3 b$ & $55.0 \mathrm{~b}$ & $66.9 \mathrm{~b}$ & $66.9 \mathrm{~b}$ \\
\hline Medium & V03-4705 & $8.1 \mathrm{a}$ & $47.2 \mathrm{ab}$ & $66.8 \mathrm{ab}$ & $74.5 \mathrm{ab}$ & $74.6 \mathrm{ab}$ \\
\hline Medium & Glenn & 11.1a & $43.7 \mathrm{ab}$ & $61.4 \mathrm{ab}$ & $69.3 \mathrm{~b}$ & $69.6 b$ \\
\hline Large & V07-1897 & $15.6 \mathrm{a}$ & $61.0 \mathrm{a}$ & $79.3 \mathrm{a}$ & $83.6 \mathrm{a}$ & $83.6 \mathrm{a}$ \\
\hline Large & MFL-159 & $9.9 \mathrm{a}$ & $46.8 \mathrm{ab}$ & $61.4 \mathrm{ab}$ & $68.1 \mathrm{~b}$ & $68.6 \mathrm{~b}$ \\
\hline
\end{tabular}

Numbers in a column followed by a similar letter are not statistically different $(P=0.05)$.

TABLE 6: Seedling emergence as a percentage of seeds planted in the field in 2014.

\begin{tabular}{|c|c|c|c|c|c|c|c|c|}
\hline \multirow{3}{*}{ Seed size class } & \multirow{3}{*}{ Variety } & \multirow{3}{*}{ Duration of water priming (hours) } & \multicolumn{6}{|c|}{ Days after planting } \\
\hline & & & 8 & 9 & 10 & 15 & 16 & 20 \\
\hline & & & \multicolumn{6}{|c|}{$\%$} \\
\hline \multirow{6}{*}{ Small } & \multirow{3}{*}{ MFS-561 } & 0 & $23.0 \mathrm{a}$ & $36.2 \mathrm{a}$ & $41.2 \mathrm{a}$ & $53.8 \mathrm{a}$ & $57.4 \mathrm{a}$ & $57.8 \mathrm{a}$ \\
\hline & & 5 & $4.4 \mathrm{~b}$ & $16.4 \mathrm{~b}$ & $20.4 b$ & $40.6 \mathrm{a}$ & $51.2 \mathrm{a}$ & $51.6 \mathrm{a}$ \\
\hline & & 10 & $11.4 \mathrm{ab}$ & $27.6 \mathrm{ab}$ & $30.6 a b$ & $45.4 \mathrm{a}$ & $46.6 \mathrm{a}$ & $48.0 \mathrm{a}$ \\
\hline & \multirow{3}{*}{ V08-4773 } & 0 & $22.2 \mathrm{a}$ & $37.4 \mathrm{a}$ & $43.6 \mathrm{a}$ & $65.6 \mathrm{a}$ & $67.6 \mathrm{a}$ & $69.0 \mathrm{a}$ \\
\hline & & 5 & $2 b$ & $6.0 \mathrm{~b}$ & $8.4 \mathrm{~b}$ & $22.0 \mathrm{c}$ & $23.8 \mathrm{c}$ & $25.8 \mathrm{~b}$ \\
\hline & & 10 & $18.0 \mathrm{a}$ & $23.6 \mathrm{a}$ & $24.8 \mathrm{a}$ & $40.4 \mathrm{~b}$ & $40.8 \mathrm{~b}$ & $39.4 \mathrm{~b}$ \\
\hline \multirow{6}{*}{ Medium } & \multirow{3}{*}{ V03-4705 } & 0 & $16.2 \mathrm{a}$ & $34.2 \mathrm{~b}$ & $47.8 \mathrm{a}$ & $61.8 \mathrm{a}$ & $63.0 \mathrm{a}$ & $63.0 \mathrm{a}$ \\
\hline & & 5 & $3.2 \mathrm{~b}$ & $7.0 \mathrm{~b}$ & $11.6 \mathrm{~b}$ & $32.0 \mathrm{~b}$ & $32.6 \mathrm{~b}$ & $29.6 \mathrm{~b}$ \\
\hline & & 10 & $19.0 \mathrm{a}$ & $31.6 \mathrm{~b}$ & $37.0 \mathrm{ab}$ & $49.6 \mathrm{a}$ & $51.2 \mathrm{a}$ & $51.6 \mathrm{a}$ \\
\hline & \multirow{3}{*}{ Glenn } & 0 & $23.6 \mathrm{~b}$ & $43.6 \mathrm{ab}$ & $54.4 \mathrm{ab}$ & $73.4 \mathrm{a}$ & $75.2 \mathrm{a}$ & $75.4 \mathrm{a}$ \\
\hline & & 5 & $57.6 a$ & $65.6 \mathrm{a}$ & $68.8 \mathrm{a}$ & $73.4 \mathrm{a}$ & $76.6 \mathrm{a}$ & $78.2 \mathrm{a}$ \\
\hline & & 10 & $20.8 \mathrm{~b}$ & $32.8 \mathrm{~b}$ & $39.8 \mathrm{~b}$ & $56.4 \mathrm{a}$ & $57.4 \mathrm{a}$ & $57.4 \mathrm{a}$ \\
\hline \multirow{6}{*}{ Large } & \multirow{3}{*}{ V07-1897 } & 0 & $2 a$ & $11.2 \mathrm{a}$ & $32.4 \mathrm{a}$ & $51.6 \mathrm{a}$ & $54.2 \mathrm{a}$ & $54.2 \mathrm{a}$ \\
\hline & & 5 & $0 \mathrm{a}$ & $0 \mathrm{~b}$ & $2.0 \mathrm{~b}$ & $7.2 \mathrm{~b}$ & $7.8 \mathrm{~b}$ & $8.6 \mathrm{~b}$ \\
\hline & & 10 & $0 \mathrm{a}$ & $0 \mathrm{~b}$ & $0 \mathrm{~b}$ & $2.0 \mathrm{c}$ & $2.0 \mathrm{c}$ & $2.8 \mathrm{~b}$ \\
\hline & \multirow{3}{*}{ MFL-159 } & 0 & $22.2 \mathrm{a}$ & $32.8 \mathrm{a}$ & 46.1a & $61.4 \mathrm{a}$ & $63.6 \mathrm{a}$ & $63.6 \mathrm{a}$ \\
\hline & & 5 & $2.0 \mathrm{~b}$ & $3.6 \mathrm{~b}$ & $4.2 \mathrm{~b}$ & $9.6 \mathrm{~b}$ & $10.6 \mathrm{~b}$ & $10.8 \mathrm{~b}$ \\
\hline & & 10 & $2.0 \mathrm{~b}$ & $3.6 \mathrm{~b}$ & $3.6 \mathrm{~b}$ & $6.8 \mathrm{~b}$ & $7.4 \mathrm{~b}$ & $7.4 \mathrm{~b}$ \\
\hline
\end{tabular}

Numbers in a column within a variety followed by a similar letter are not statistically different $(P=0.05)$.

and large-seeded varieties in 2013 and difference observed in 2014 among varieties of different seed sizes could be a result of prevailing soil condition.

\section{Conclusions}

Despite better germination of small- and medium-seeded varieties in the laboratory, inherent field moisture at planting may be more important than seed size for germination and emergence. Similarly, presoaking seeds prior to planting may initiate germination process, but on planting, growth may be arrested under dry field conditions with potential loss of seed viability. Under conditions of low moisture content, slight irrigation may favor emergence of small-seeded varieties. However, moisture levels should be enough to allow seed to imbibe, germinate, and emerge above the soil surface. Under insufficient moisture, small seeds may imbibe, germinate, and die while in large seeds imbibed water may be insufficient to trigger germination and such seeds may emerge later when conditions improve. Alternatively, soil moisture sufficient to allow emergence of small seeds may allow germination in large seeds but could be insufficient to sustained seedling growth and emergence. Hydropriming and $\mathrm{N}$ application applied simultaneously in field planting may affect seedling emergence through promoting premature germination and osmotic dehydration. Its benefits may only be realized under certain prevailing field conditions. Therefore, more studies in multiple locations are needed on multiple varieties, priming, and seed size effects on emergence for a more definitive conclusion. Studies are needed on priming and seed size at 
controlled soil moisture to answer question on whether to irrigate and how much irrigation is needed for optimum seedling emergence for different sized seeds.

\section{Conflict of Interests}

The authors declare that there is no conflict of interests regarding the publication of this paper.

\section{Acknowledgment}

The authors thank the Virginia Agricultural Council for funding this project.

\section{References}

[1] D. Johnson, "Edamame: Westerners develop a taste for Japanese soybean," Engineering Technology for Sustainable World, vol. 7, pp. 11-12, 2000.

[2] L. Zhang and S. Kyei-Boahen, "Growth and yield of vegetable soybean (Edamame) in Mississippi," HortTechnology, vol. 17, no. 1, pp. 26-31, 2007.

[3] K. Lazor, N. Chapman, and E. Levine, "Soy goes to school: acceptance of healthful, vegetarian options in Maryland middle school lunches," Journal of School Health, vol. 80, no. 4, pp. 200 206, 2010.

[4] Soyfoods Association of North America, "The U.S. Market 2014," September 2015, http://www.soyfoods.org/products/ sales-and-trends.

[5] A. P. Gandhi, "Quality of soybean and its food products," International Food Research Journal, vol. 16, no. 1, pp. 11-19, 2009.

[6] H. L. Bhardwaj, A. S. Bhagsari, J. M. Joshi, M. Rangappa, V. T. Sapra, and M. S. S. Rao, "Yield and quality of soymilk and tofu made from soybean genotypes grown at four locations," Crop Science, vol. 39, no. 2, pp. 401-405, 1999.

[7] H. L. Bhardwaj, A. A. Hamama, M. Rangappa, J. M. Joshi, and V. T. Sapra, "Effects of soybean genotype and growing location on oil and fatty acids in tofu," Plant Foods for Human Nutrition, vol. 58, no. 3, pp. 197-205, 2003.

[8] R. R. Johnson and L. M. Wax, "Relationship of soybean germination and vigor tests to field performance," Agronomy Journal, vol. 70, no. 2, pp. 273-278, 1978.

[9] T. J. Smith and H. M. Camper Jr., "Effect of seed size on soybean performance," Agronomy Journal, vol. 67, no. 5, pp. 681-684, 1975.

[10] D. J. Hoy and E. E. Gamble, "Field performance in soybean with seeds of differing size and density," Crop Science, vol. 27, no. 1, pp. 121-126, 1987.

[11] S. K. S. Roy, A. Hamid, M. G. Miah, and A. Hashem, "Seed size variation and its effects on germination and seedling vigour in rice," Journal of Agronomy and Crop Science, vol. 176, no. 2, pp. 79-82, 1996.

[12] W. R. Cookson, J. S. Rowarth, and J. R. Sedcole, "Seed vigour in perennial ryegrass (Lolium perenne L.): effect and cause," Seed Science and Technology, vol. 29, no. 1, pp. 255-270, 2001.

[13] S. M. Mohan Mandal, D. Chakraborty, and K. Gupta, "Seed size variation: influence on germination and subsequent seedling performance in Hyptis suaveolens (Lamiaceae)," Research Journal of Seed Science, vol. 1, no. 1, pp. 26-33, 2008.
[14] J. S. Burris, O. T. Edje, and A. H. Wahab, "Effects of seed size on seedling performance in soybeans: II. Seedling growth and photosynthesis and field performance," Crop Science, vol. 13, no. 2, pp. 207-210, 1973.

[15] E. Stobbe, J. Moes, Y. Gan, H. Ngoma, and L. Bourgeca, Seeds, Seed Vigor and Seeding Research Report, Department of Plant Science, NDSU Agriculture and University Extension, Fargo, ND, USA, 2008.

[16] E. Peksen, A. Peksen, H. Bozoglu, and A. Gulumser, "Some seed traits and their relationships to seed germination and field emergence in pea (Pisum sativum L.)," Journal of Agronomy, vol. 3, no. 4, pp. 243-246, 2004.

[17] D. R. Johnson and V. D. Luedders, "Effect of planted seed size on emergence and yield of soybean (Glycine max (L.) Merr.)," Agronomy Journal, vol. 66, no. 1, pp. 117-118, 1974.

[18] T. K. Bejandi, M. Sedghi, R. S. Sharifi, A. Namvar, and P. Molaei, "Seed priming and sulfur effects on soybean cell membrane stability and yield in saline soil," Pesquisa Agropecuária Brasileira, vol. 44, no. 9, pp. 1114-1117, 2009.

[19] W. A. Pereira, S. M. A. Pereira, and D. Denise Cunha Fernandes dos Santos, "Influence of seed size and water restriction on germination of soybean seeds and on early development of seedlings," Journal of Seed Science, vol. 35, no. 3, pp. 316-322, 2013.

[20] D. Harris, A. K. Pathan, P. Gothkar, A. Joshi, W. Chivasa, and P. Nyamudeza, "On-farm seed priming: using participatory methods to revive and refine a key technology," Agricultural Systems, vol. 69, no. 1-2, pp. 151-164, 2001.

[21] C. J. Edwards Jr. and E. E. Hartwig, "Effect of seed size upon rate of germination in soybeans," Agronomy Journal, vol. 63, pp. 429-430, 1971.

[22] D. Harris and M. Jones, "On farm seed priming to accelerate germination in rainfed, dry seed rice," International Rice Research Notes, vol. 22, no. 2, pp. 22-30, 1997.

[23] F. S. Murungu, C. Chiduza, P. Nyamugafata, L. J. Clark, and W. R. Whalley, "Effect of on farm seed priming on emergence, growth and yield of cotton and maize in a semiarid area of Zimbabwe," Experimental Agriculture, vol. 40, no. 1, pp. 23-36, 2004.

[24] K. Ghassemi-Golezani, S. Farshbaf-Jafari, and J. ShafaghKolvanagh, "Seed priming and field performance of soybean (Glycine max L.) in response to water limitation," Notulae Botanicae Horti Agrobotanici Cluj-Napoca, vol. 39, no. 2, pp. 186189, 2011.

[25] G. S. Giri and W. F. Schillinger, "Seed priming winter wheat for germination, emergence, and yield," Crop Science, vol. 43, no. 6, pp. 2135-2141, 2003. 


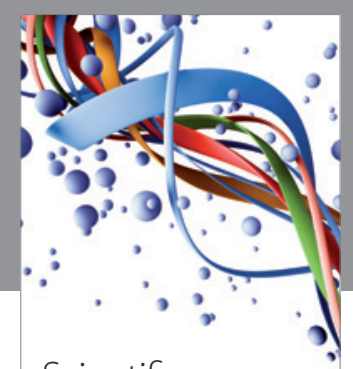

Scientifica
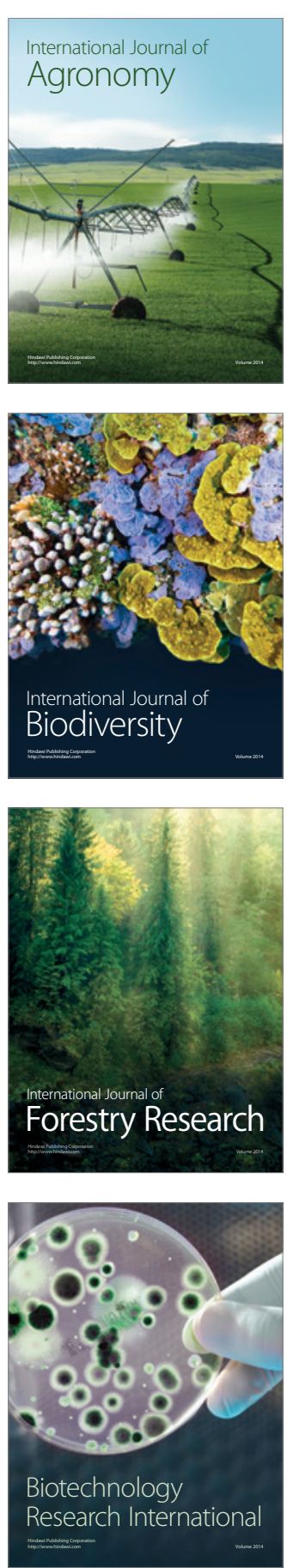
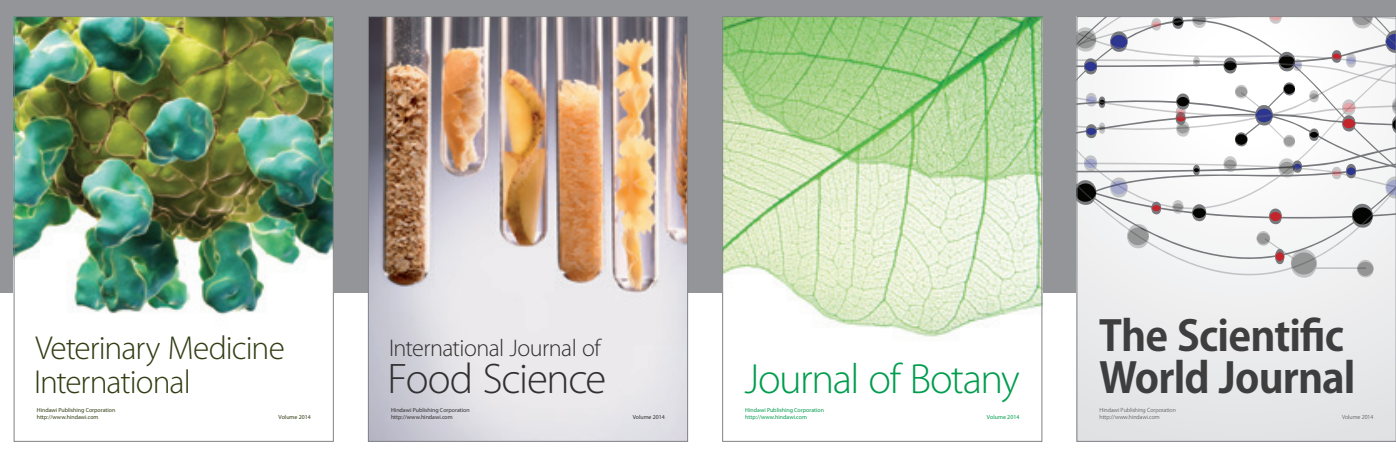

The Scientific World Journal
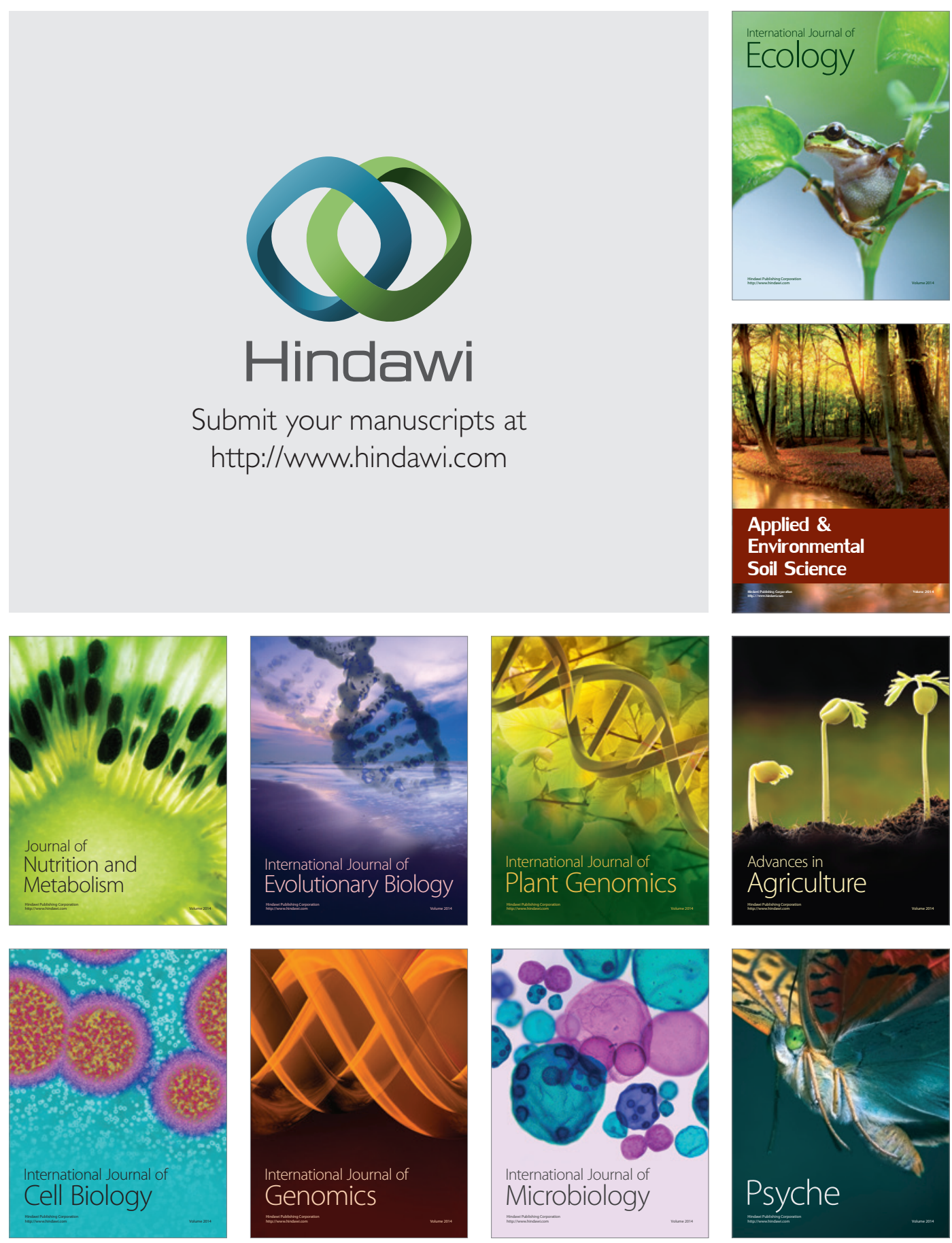